Article

\title{
International Market Leakage from China's Forestry Policies
}

Xin Hu ${ }^{1,2, *}$, Guoqing Shi ${ }^{2}$ and Donald G. Hodges ${ }^{3}$

1 Business College, Hohai University, Nanjing 211100, China

2 National Research Center for Resettlement, Hohai University, Nanjing 210098, China;

E-Mail: gshi@hhu.edu.cn

3 Natural Resource Policy Center, Department of Forestry, Wildlife and Fisheries, The University of Tennessee, Knoxville, TN 37996-4563, USA; E-Mail: dhodges2@utk.edu

* Author to whom correspondence should be addressed; E-Mail: hu.xin.1987@hotmail.com or lovecatherine@hhu.edu.cn; Tel.: +86-158-9584-6746; Fax: +86-25-8371-8914.

External Editor: Eric J. Jokela

Received: 10 October 2014; in revised form: 27 October 2014 / Accepted: 31 October 2014 /

Published: 5 November 2014

\begin{abstract}
Carbon leakage can be a problem when seeking to reduce carbon emissions through forest policy. International market leakage is mainly caused by supply and demand imbalances in the timber market. This paper selects China, which is implementing forestry policy changes, as the research object. We begin by offering a brief analysis of China's forestry policy changes, such as the logging quota and Six Key Forestry Programs to determine whether those policies affect timber supply. Second, through the use of three shock variables, carbon leakage is simulated under different scenarios by the Global Trade Analysis Project (GTAP) model. The results reveal that the magnitude of leakage caused by implementing China's forestry policies is between $79.7 \%$ and $88.8 \%$ with carbon leakage mainly displaced to Russia, Southeast Asia, and the EU. Two effective scenarios for reducing market leakage are presented: forest tenure reform and fast growing forest projects to improve domestic timber production, and raising tariffs on timber imports to reduce imports.
\end{abstract}

Keywords: market leakage; China; forestry policies; global trade analysis project 


\section{Introduction}

Forests can play a critical role in addressing climate change. Approximately $17.4 \%$ of the annual global carbon dioxide emissions are caused by deforestation and forest degradation, placing the potential contribution of forest loss to climate change above that of the transportation and industrial sectors. Thus it will be impossible to solve the climate change problem without addressing these emissions [1]. As is well known, forests remove carbon from the atmosphere and release oxygen through photosynthesis, and they can sequester carbon both in their biomass and soils. Forests are the world's most important terrestrial carbon "sink", or storehouse of carbon [2]. Therefore international organizations, nations, and scientists are looking for a way to more effectively mitigate climate change through forest growth and carbon sequestration.

The Copenhagen Conference (COP15) proposed establishing a Reducing Emissions from Deforestation and forest Degradation Plus (REDD+) mechanism [3]. This contains a comprehensive set of measures related to forests, such as reducing deforestation and forest degradation, afforestation/reforestation, sustainable forest management, and forest conservation to reduce emissions. However, implementing REDD+ policies faces many challenges, including the potentially negative impacts of REDD+ funding [4], breaking the low-carbon energy system (REDD is a cost effective method to mitigate climate change. If REDD credits are allowed to enter the carbon market, it will drastically reduce carbon prices, and possibly lower the incentive to develop energy and carbon saving technologies) [5] and leakage [6]. As a result, the REDD + mechanism has not been supported by all parties to the United Nations Framework Convention on Climate Change (UNFCCC) and has not become an effective tool for mitigating global climate change.

Some researchers recently have begun addressing the issue of leakage. The IPCC Special Report on Land Use, Land Use Change and Forestry defines leakage as "the unanticipated decrease or increase in greenhouse gas (GHG) benefits outside of the project's accounting boundary as a result of project activities" [7]. Aukland et al. [8] describe two main categories or types of leakage: activity leakage (or "primary leakage") and market leakage (or "secondary leakage"). Activity leakage refers to direct leakage effects caused by displacing baseline activities or agents from one area to the next. Market leakage occurs when the intervention changes market price signals and provides incentives for conducting new emission generation activities outside the intervention boundary.

Leakage within one country can be measured by establishing a national carbon monitoring system, while international leakage is much more complex to measure. This research is only focused on international market leakage. Market leakage is usually caused by a reduction in the supply of commercial products (e.g., timber), which leads to a shift in market equilibrium [9]. That is, if a country implements a policy to decrease timber supply, then timber prices will rise, which will trigger increased supply (and potentially increased harvest levels) in other countries. A number of studies have addressed the issue of leakage arising from forest policies. Paltsev [10] suggested that compared to leakage from chemical, iron, and steel, activities related to land use, land use change, and forestry displace negligible amounts of carbon across regional boundaries. Sun and Sohngen [11] and Gan and McCarl [12] examined leakage models that include emissions from land use change and forests. Sun and Sohngen's model is better suited for the biophysical variability across regions by taking into account the diversity of $\mathrm{C}$ density in different parts of the world. For every ton of $\mathrm{C}$ saved from setting 
aside forestland, an estimated $0.47-0.52 \mathrm{t}$ of $\mathrm{C}$ is released from forest conversion in other parts of the world. Gan and McCarl used a Computable General Equilibrium (CGE) model to estimate 42\%-95\% leakage occurring when a country/region reduced forest production. Meyfroidt and Lambin [13] used Material Flow Analysis and estimated that 39\% of the regrowth of Vietnam's forests between 1987 and 2006 was enabled by an international shift in forest exploitation and imports.

Since the People's Republic of China was founded in 1949, the government has launched several large-scale forestation and forest conservation initiatives. Its forest cover increased from $8.6 \%$ to $20.36 \%$, resulting in an area of manmade forest of 61.69 million hectares, more than any other country [14]. However, the 1998 logging ban in China resulted in a substantial displacement of forest exploitation to Russia and Southeast Asian countries with weak regulatory regimes $[15,16]$. Fearnside et al. [17] argued that China's increasing import demand for timber caused an increase in the deforestation of the Brazilian Amazonia. Laurance [18] reported that much of China's imported timber is illegally harvested and influences the global environment.

This report examines international market leakage induced by China's forest policies and linkages to market supply. A brief assessment of China's forestry policy is presented, as are results of an analysis of leakage and displacement caused by China's forest policies under four different simulation scenarios.

\section{China's Forest Policy}

In 1998, the south of China suffered a rare flood, which resulted in significant losses for the government and people. The resulting analysis revealed that logging played a significant role, and as a consequence, China initiated a program to increase environmental awareness and attention to forests. China subsequently adopted a series of policies and initiated projects, such as the Natural Forest Conservation Program (NFCP), an initiative that has resulted in remarkable success in protecting forest resources and increasing forest coverage. In doing so, however, it ignored the potential market leakage. As previously noted, the main reason for market leakage is that the policy reduced market supply. Therefore, our analysis encompasses the period after 1998.

\subsection{Logging Quota System}

China implemented a logging quota management system in 1987. The basic principle is that the logging amount cannot exceed forest growth. Every year the State Forestry Administration audits the total quantity of logging, and reports to the State Council for approval, and then progressively allocates quotas to the provinces, municipalities, and counties. The State Council re-approves the annual logging quotas every five years. After 1998, faced with a worsening ecological environment, China banned natural forest logging in the upper reaches of the Yangtze River and in the middle and upper reaches of the Yellow River, and then reduced timber production in the Northeast of China and Inner Mongolia. The logging quota was greatly reduced (see Table 1), leading to a shortage of domestic timber. 
Table 1. Annual logging quota (1991-2015).

\begin{tabular}{cc}
\hline Period & Annual Logging Quota $\left(\right.$ million $\mathbf{~ m}^{\mathbf{3}}$ ) \\
\hline $1991-1995$ & 243.6 \\
$1996-2000$ & 266.5 \\
$2001-2005$ & 233.1 \\
$2006-2010$ & 248.2 \\
$2010-2015$ & 271.1 \\
\hline
\end{tabular}

\subsection{Six Key Forestry Programs}

Beginning in 2000, China gradually implemented the Six Key Forestry Programs (SKFPs) [19]. This includes the NFCP, the Sloping Land Conversion Program, the Desertification and Dust Storms Control Program in the vicinity of Beijing and Tianjin Municipalities, the Forest Shelterbelt Development Program in key environmentally fragile regions, the Wildlife Conservation and Nature Reserves Development Program, and the Fast-Growing and High-Yield Timber Plantations Program (FGHY). The former five programs' main functions are natural forest conservation and ecological forest plantations. As an example of impact of NFCP, timber production in the conservation areas in 2009 totaled 14.84 million $\mathrm{m}^{3}$, a decrease of $11.6 \%$ from 2008 ; and cumulatively tree planting totaled 2.66 million hectares [14]. The FGHY program was officially launched in 2002 with the purpose of supplementing market supply. By 2009, it had created a total of 0.21 million hectares of fast growing timber [14].

\subsection{Collective Forest Tenure Reform}

China's forest sector consists of two basic types of forestland ownership: state ownership and collective ownership. This ownership system restricts the enthusiasm of farmers for forestation, forest protection, and forest production. In the collective ownership system, forest income belongs to all members of the collective rather than the person who creates the forest. Since 2003, on the premise of unchanged collective ownership, China launched collective forest tenure reform by implementing the Rural Land Contract Law. This re-allocates the tenure right of forest land and forest to individual households, defining forestry business entities, and activating forestry businesses.

As of 2011, 20 provinces (autonomous regions/municipalities) have completed the reformed task of clarifying property rights and contracting with individual households; a total of 162 million $\mathrm{hm}^{2}$ of forestland has been contracted, accounting for $88.8 \%$ of the total area of collective forest land. Moreover, 72.6 million farmers received forest certificates and more than 300 million farmers directly benefited from the reform [20]. With forest reform in full swing, its supporting measures, such as relaxing logging quotas and reducing the forestry tax, will create favorable conditions for increasing the domestic supply of logs in the short term.

\subsection{Adjustment of Timber Import Tariff}

After implementing the logging ban and large forest protection programs, China's natural forest timber supply dropped. To offset the reduction in domestic timber supply, China adjusted import 
tariffs on roundwood and sawn timber to zero and cancelled restrictions on timber imports and exports in 1999. The result was an era of sharply increasing timber imports. Forest products imports subsequently surged, with forest products import volume reaching nearly 90 million $\mathrm{m}^{3}$ in 2011, almost eight times that of 1997, and making China the world's leading importer of industrial round wood [16].

\section{Methods}

The magnitude of leakage is commonly expressed in proportional or percentage terms for the relationship between GHG emissions shifted elsewhere and GHG directly reduced by the policy [21]. In this paper, we use timber production instead of GHG emissions, and apply the GTAP model (Global Trade Analysis Project), a general equilibrium model, to simulate leakage under different situations.

\subsection{GTAP Model}

The general equilibrium model can portray how different decision making regarding supply and demand by various economic actors affect specific goods, factors, and prices. In general, the quantity and price of all goods and factors are endogenously determined simultaneously in the equilibrium model. Thus, the model considers the interaction of the entire economy in a consistent manner, and can predict the impact caused by several potential policy changes. This paper uses the GTAP model [22] and its database of Version 7, which contains data for 57 sectors (commodity groups) and 113 countries/regions with a base year of 2004.

GTAP is the world's largest computable general equilibrium model of trade liberalization. The GTAP model assumes that markets are perfectly competitive: production has constant returns-to-scale, producers minimize production costs, consumers maximize utility, and all markets of output and input are at equilibrium. The production process is represented by a nested constant elasticity of substitution (CES). Products are differentiated by country of origin using the [23] structure. In the factor market, labor is assumed to be mobile between industries/sectors, whereas land is immobile across countries/regions. Therefore, the prices of land can vary by country. Each country/region has only one account, and all taxes and income are accumulated to the account. Through the Cobb-Douglas utility function, all income is assigned to private consumption, government consumption, and savings in fixed proportions. Private consumption is determined by the Constant Difference of Elasticity (CDE) utility function; Cobb-Douglas utility function is used for determining government consumption. Additionally, there are two international departments (global banks and international transport sectors) in the GTAP model. Savings of each country pool to "the global bank", and allocate to various countries according to the rates of return on capital. The "international transport sector" is mainly responsible for production transportation among various regions, and balancing the difference between the f.o.b (free on board) and c.i.f. (cost, insurance, and freight) values. The structure and behavioral equations of the GTAP model can be found in Hertel [22]. 


\subsection{Regional and Sectoral Aggregation}

To analyze the impact of China's forest policies on the world forest/agricultural market and leakage, we aggregated the GTAP countries/regions into eight regions with each representing either a single country or a composite region consisting of several countries (Table 2): China (CHN), North America (NAM), the European Union (EU), Oceania (OCN), Russia (RUS), Southeast Asia (SEA), Latin America (LAM) and the rest of the world (ROW). The regions were aggregated primarily based on their importance in international trade (particularly with China) of forest/agricultural products, current forest/agriculture conditions and management practices, economic development status, and geographic location. Each region's economy was further aggregated into nine sectors (Table 2): forestry (FOR), lumber and wood products (LUM), pulp and paper (PPR), agriculture (AGR), food processing (FOD), mining and Extraction (EXT), manufacturing (MNF), construction and dwelling (CND), and services (SVS), reflecting the study emphasis on forestry and related sectors.

Table 2. Regional and sectoral aggregation.

\begin{tabular}{llll}
\hline Regional Identifier & Country/Region & Sectoral Identifier & Sector \\
\hline CHN & China including Hong Kong & FOR & Forestry \\
NAM & North America & LUM & wood products \\
EU & European Union & PPP & Paper Products, Publishing \\
OCN & Oceania & AGR & Agriculture \\
RUS & The Russia Federation & FOD & Food processing \\
SEA & Southeast Asia & EXT & Mining and Extraction \\
LAM & Latin America & MFG & Manufacturing \\
ROW & The rest of the world & CND & Construction and dwelling \\
& & SVC & Services \\
\hline
\end{tabular}

\subsection{Simulation Design}

Considering the effect of China's forestry policy on leakage, this paper examines three exogenous shock variables: (i) logging quota policy and logging bans/limits, policies on harvesting natural forests leading to a $10 \%$ reduction in the supply of timber [16]; (ii) tenure reform of collectively owned forests and fast growing trees program resulting in a timber supply increase of 5\% [24]; and (iii) increases in timber import tariffs of 5\%. The three shock variables were used to compose four scenarios (Table 3). Scenario I reflects the independent effect of shock variable (i); scenarios II to IV are combinations of different shock variables. To ensure the requirement for model closure (the requirement for a unique solution of the model) the simulation is accomplished by swapping the variable "output" with the variable "output tax" for the Chinese forestry sector. 
Table 3. Shock variables and Simulation scenarios.

\begin{tabular}{|c|c|}
\hline & Description \\
\hline \multicolumn{2}{|c|}{ Shock } \\
\hline i & Logging quota system and logging ban/limit harvesting of natural forest policies \\
\hline ii & Collective owned forest tenure reform and fast growing trees program \\
\hline iii & Timber import tariff \\
\hline \multicolumn{2}{|c|}{ Scenario } \\
\hline I & Reduction of Chinese timber production by $10 \%$ \\
\hline II & Combination of the impact of the variable 1 and 2, Chinese timber production reduced by $5 \%$ \\
\hline III & $\begin{array}{l}\text { The variable } 1 \text { and } 3 \text {, Chinese timber production decreases by } 10 \% \text {, and tariffs on timber imports } \\
\text { increases by } 5 \%\end{array}$ \\
\hline IV & $\begin{array}{l}\text { Combination of the impact of three variables, Chinese timber production falls by } 5 \% \text {, and timber } \\
\text { import tariff increases by } 5 \%\end{array}$ \\
\hline
\end{tabular}

\section{Results and Discussion}

\subsection{Impact on World Market and China's Imports and Exports}

When Chinese timber production was reduced by $10 \%$ (scenario I) and 5\% (scenario II), the price of international timber increased at almost the same pace, while the production of international timber decreased by only $0.67 \%$ and $0.29 \%$, respectively (Table 4). This is consistent with general equilibrium theory: a decrease in a country's timber production due to the implementation of forest protection policies reduces timber supply. With no changes in demand, international timber prices will increase. Through international trade, other countries will raise their timber production until a new equilibrium in regional and global timber markets achieved. Thus, reducing Chinese timber production stimulates international timber prices. Due to rising timber prices, other countries/regions increase their timber production in order to obtain higher revenues. Because world trade closely links countries/regions, the world's timber production decreases only slightly. The increase in global import and export also confirms the process of market equilibrium. In this scenario, the growth rate is almost twice the rate of decline in China's timber production.

Table 4. Percentage changes in China's imports and exports and global markets of forestry section.

\begin{tabular}{ccccccc}
\hline Scenario & $\begin{array}{c}\text { World } \\
\text { Output }\end{array}$ & $\begin{array}{c}\text { World } \\
\text { Price }\end{array}$ & $\begin{array}{c}\text { World's } \\
\text { Imports }\end{array}$ & $\begin{array}{c}\text { World's } \\
\text { Exports }\end{array}$ & $\begin{array}{c}\text { China's } \\
\text { Imports }\end{array}$ & $\begin{array}{c}\text { China's } \\
\text { Exports }\end{array}$ \\
\hline I & -0.67 & 10.62 & 20.73 & 20.80 & 110.08 & -68.39 \\
II & -0.29 & 5.03 & 8.97 & 9.02 & 47.70 & -44.20 \\
III & -0.67 & 10.64 & 17.31 & 17.39 & 91.51 & -69.03 \\
IV & -0.27 & 5.06 & 6.48 & 6.54 & 34.12 & -45.16 \\
\hline
\end{tabular}

Compared to scenarios I and II, the shock of an increase in China's timber import tariff of 5\% (scenarios III and IV) combined with the impact of reduced Chinese timber production results in relatively minor effects on global timber production and the increased Chinese import tariff restrains the growth of total international timber imports and exports. The growth rates of global imports are reduced by $3.4 \%$ and $2.5 \%$ respectively. The growth rates of world exports also decrease. 
The implementation of forest preservation policies has a substantial influence on China's imports and exports. When Chinese timber production decreased by $10 \%$, total timber imports more than doubled, and exports were reduced by two-thirds. That situation will change when timber production increases through tenure reform and FGHY. The quantity of imports (exports) increase (decrease) almost 50\%. After the increase in timber import tariffs, imports of wood decline; however, there is not much impact on exports. Increases in China's timber imports illustrates that Chinese forest policy has a displacement effect leading to timber exports to China (Table 5).

Table 5. Percentage changes in exports to China.

\begin{tabular}{cccccccc}
\hline Scenario & OCN & SEA & RUS & NAM & LAM & EU & ROW \\
\hline I & 113.91 & 114.17 & 97.63 & 132.61 & 133.46 & 131.79 & 131.02 \\
II & 49.02 & 49.00 & 43.99 & 54.30 & 54.47 & 54.06 & 53.95 \\
III & 94.55 & 94.36 & 82.23 & 108.38 & 109.14 & 107.86 & 107.51 \\
VI & 35.01 & 34.79 & 31.82 & 38.36 & 38.52 & 38.24 & 38.30 \\
\hline
\end{tabular}

\subsection{Leakage}

Through international trade, China's reduced timber production plays a role in other countries/regions (Table 6), increasing their timber production appreciably. In all four scenarios, the growth rates of timber production in Russia, Southeast Asia and Oceania increase, most notably that of Russia, which increase by essentially the same amount of China's reduction. This may be related to their position in the timber trade with China (to be discussed later in 4.3).

Table 6. Changes in timber production and leakage.

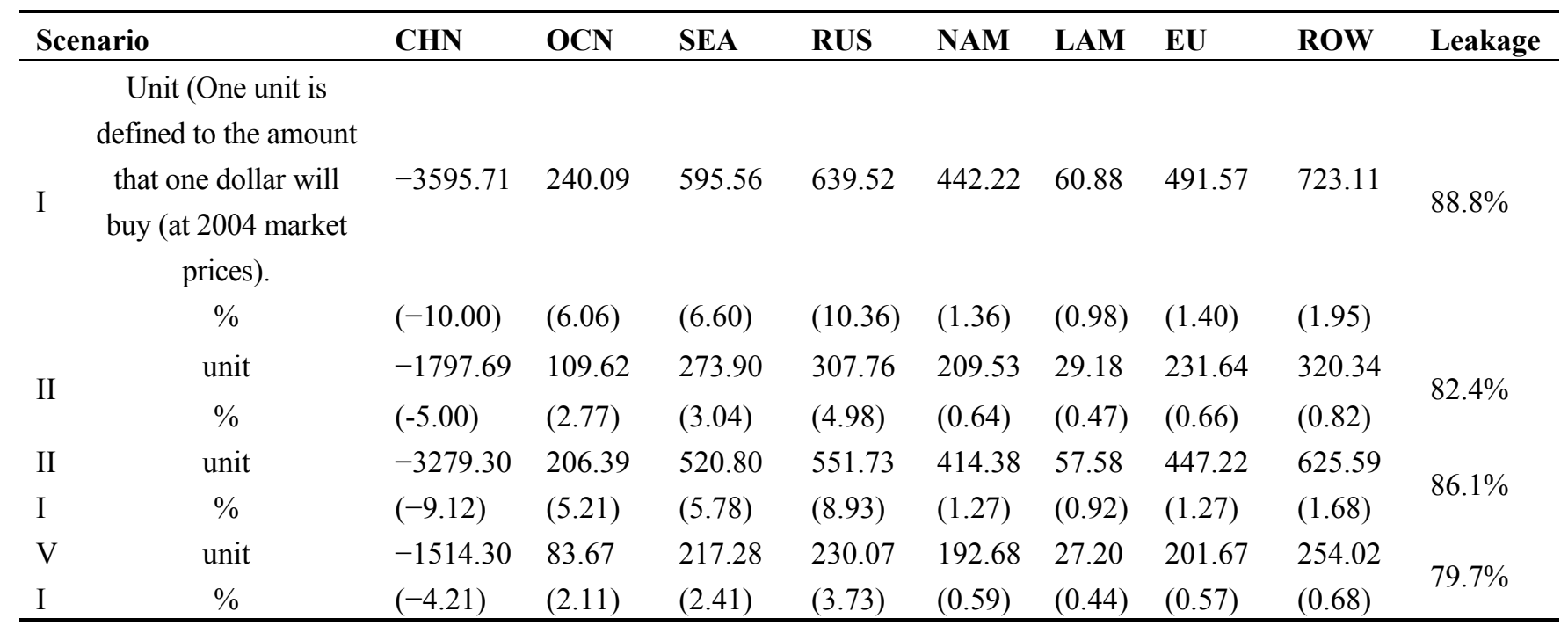

The amount of leakage is calculated by the ratio of the net change of timber production in other parts of the world and China (Table 6). When China implements a logging ban or limits harvesting in natural forests, the magnitude of leakage is maximized at $88.8 \%$. After implementing tenure reform and FGHY, and the subsequent increase in domestic timber supply, the amount of leakage is reduced to $82.4 \%$. International market leakage occurs when the timber market supply and demand imbalance caused by one country's actions, affects forest conservation efforts of another. Through the role of 
markets and international trade, other regions and countries increase timber production to achieve the market re-equilibrium. Simultaneously, carbon leakage is generated. It should be noted that although implementing FGHY and forest tenure reform will increase the domestic timber supply, the maturity of wood requires 5-10 years, or even longer, whereas a logging ban reduces timber supply immediately [25]. That is, although in a perfect market, the leakage effects of forest protection policies can be offset by afforestation/reforestation, it is much more difficult to achieve this in real market conditions.

Rising tariffs on timber imports (scenarios III and IV), affect the amount of leakage. This is mainly because as China's timber import tariff increases, the demand for timber imports declines (Table 4) which, in turn, reduces other counties' timber production and exports to China (Table 5).

Simulation results reveal that the amounts of leakage caused by China's forest policies are $88.8 \%$ and $82.4 \%$. If raising the wood import tariff, the leakage will be reduced to $86.1 \%$ and $79.7 \%$, respectively. It is worth noting, however, that this study did not account for forest carbon density. According to FAO, the carbon stock in living biomass contained in Chinese forestlands in 2010 averaged $121.4 \mathrm{mg} / \mathrm{ha}$, much less than the world average [26]. If the forest carbon density between different regions is considered, the magnitude of leakage caused by China's forest conservation policies may be larger.

\subsection{Leakage Displacement}

International market leakage is achieved through the transfer of timber production. Timber production triggered by Chinese forest policy mainly displaces to Russia (20.0\%), Southeast Asia (18.7\%), EU (15.4\%), North America (13.8\%), Oceania (7.5\%), Latin America (1.9\%) and other regions (22.6\%). As previously mentioned, growth rates of timber production in Russia, Southeast Asia and Oceania are relatively high. This has a certain relationship with their position in the Chinese import market (Table 7) as these three regions are the leading timber exporters to China, accounting for $77.4 \%$ of China's timber import market. After China's forest protection policies are implemented, these three regions still occupy more than half of China's timber import market, although other countries/regions also enhance their timber exports to China and increase their share of China's import market.

Table 7. Shares (\%) in China's import markets.

\begin{tabular}{cccccccc}
\hline Scenario & OCN & SEA & RUS & NAM & LAM & EU & ROW \\
\hline Base (2004) & 9.89 & 24.55 & 42.94 & 4.11 & 0.21 & 3.23 & 14.99 \\
I & 10.03 & 24.95 & 40.20 & 4.55 & 0.24 & 3.57 & 16.46 \\
II & 9.97 & 24.73 & 41.77 & 4.29 & 0.22 & 3.37 & 15.61 \\
III & 10.02 & 24.84 & 40.69 & 4.47 & 0.23 & 3.51 & 16.22 \\
VI & 9.95 & 24.65 & 42.14 & 4.24 & 0.22 & 3.33 & 15.45 \\
\hline
\end{tabular}

In addition, Table 5 illustrates the changes of other countries/regions timber exports to China in four different scenarios. In all four scenarios, there are growth trends of timber exports to China in all regions. Increases in China's timber import duties will reduce the attractiveness of exports of other countries/regions to China to some extent. 
Combined with the production increase in other countries and regions (Table 6), increasing timber exports to China further indicate that implementing China's forest policy changes has a carbon leakage effect. Other countries/regions increase timber production and raise the timber exports to China, which offset the decrease in Chinese timber production.

\section{Conclusions}

International trade can promote the efficient allocation of resources. However, as the world jointly strives to mitigate climate change, international trade does not always play a proper role in all countries/regions forest preservation policies. In this paper, after a brief analysis of the impact of China's forest policy on the domestic timber supply, we used the GTAP model to simulate the leakage caused by China's forestry policy under four different scenarios. The leakage of the four scenarios averaged $84.3 \%$, which indicates that the net carbon sinks resulting from implementing China's forest policy are less than $16 \%$. While China continues to increase its forest coverage through the Six Key Forestry Programs, the results of the policies are not satisfactory from a carbon sequestration perspective.

We cannot simply rely on reducing deforestation to achieve the effects of increasing carbon sinks, because it is likely to generate carbon leakage. This study revealed that increasing domestic timber production and reducing timber imports are two effective methods of reducing carbon leakage for China. The fast growing and high yielding Timber Base Construction Program launched in 2002 has begun to complement market supply. Through sustainable timber management and increasing afforestation areas, these plantations will complement China's domestic timber market in the future. Furthermore, forest tenure reform is almost complete, which will allow farmers more autonomy in forest management decisions, thereby improving timber production. Both increased domestic timber supply policies are beneficial, because they not only ease the shortage of domestic wood, but also allow forest managers to realize a profit. Conversely, people would not prefer increased timber import tariffs. Raising tariffs will increase the cost of imported timber, thereby increasing processing costs for businesses and consumer cost. However, the reduction in imports means less demand for wood. Other countries and regions will reduce their timber production and achieve the goal of reducing carbon leakage. In addition, the first method of increased domestic timber supply also reduces the cost of domestic wood consumption to some extent. Therefore, a good emission-reduction policy should be a combination of a variety of different measures. The co-operation between countries and regions in forest protection will also play a role in reducing carbon leakage [12]. The REDD+ mechanism, which uses forestry as a primary means to reducing emissions is widely recognized. Through establishing a global carbon monitoring system and strengthening international co-operation in the future, the amount of carbon leakage can be effectively controlled.

Because international leakage occurs across international borders and the difficulty in identifying the linkages, it is particularly hard to directly monitor and quantify market leakage. This research uses the GTAP model to estimate the magnitude of leakage. This approach possesses certain weaknesses; however, including the fact that the degree of leakage could be exaggerated as the level of aggregation with regards to commodities/sectors can be quite large if implicitly assuming perfect substitution. 
Further work is needed to identify and assess leakage monitoring and measuring methods in order to address the carbon accounting issue brought by REDD.

\section{Acknowledgement}

We would like to thank the anonymous reviewers for the constructive comments and suggestions.

\section{Author Contributions}

Xin $\mathrm{Hu}$ and Guoqing Shi conceived and designed the research; Xin Hu performed the model; Xin $\mathrm{Hu}$ and Donald G. Hodges analyzed the data; Xin Hu wrote the paper.

\section{Conflicts of Interest}

The authors declare no conflict of interest.

\section{References}

1. IPCC Summary for Policymakers. In Climate Change 2007: Synthesis Report. Contribution of Working Groups I, II and III to the Fourth Assessment Report of the Intergovernmental Panel on Climate Change; IPCC: Geneva, Switzerland, 2007.

2. Hirsch, D.D. Trading in Ecosystem Services: Carbon Sinks and the Clean Development Mechanism. J. Land Use Environ. Law 2006, 22, 623.

3. Methodological Guidance for Activities Relating to Reducing Emissions from Deforestation and Forest Degradation and the Role of Conservation, Sustainable Management of Forests and Enhancement of Forest Carbon Stocks in Developing Countries; Draft Conclusions Proposed by the Chair, Subsidiary Body for Scientific and Technological Advice (SBSTA), Thirty-Fourth Session, Bonn, Germany; United Nations Office: Geneva, Switzerland, 2011.

4. Agrawal, A.; Nepstad, D.; Chhatre, A. Reducing emissions from deforestation and forest degradation. Annu. Rev. Environ. Resour. 2011, 36, 373-396.

5. Bosello, F.; Eboli, F.; Parrado, R.; Rosa, R. REDD in the carbon market: A general equilibrium analysis. FEEM Note Lavoro 2010, 2010, 1-20.

6. Gupta, J.; van der Grijp, N.; Kuik, O. Climate Change, Forests and REDD: Lessons for Institutional Design; Routledge: Oxford, UK, 2013.

7. Watson, R.T.; Noble, I.R.; Bolin, B.; Ravindranath, N.; Verardo, D.J.; Dokken, D.J. Land Use, Land-Use Change and Forestry: A Special Report of the Intergovernmental Panel on Climate Change; Cambridge University Press: Cambridge, UK, 2000.

8. Aukland, L.; Costa, P.M.; Brown, S. A conceptual framework and its application for addressing leakage: the case of avoided deforestation. Clim. Policy 2003, 3, 123-136.

9. Henders, S.; Ostwald, M. Forest carbon leakage quantification methods and their suitability for assessing leakage in REDD. Forests 2012, 3, 33-58. 
10. Paltsev, S.V. The Kyoto Protocol: Regional and sectoral contributions to the carbon leakage. Energy J. 2001, 53-79.

11. Sun, B.; Sohngen, B. Set-asides for carbon sequestration: Implications for permanence and leakage. Clim. Chang. 2009, 96, 409-419.

12. Gan, J.; McCarl, B.A. Measuring transnational leakage of forest conservation. Ecol. Econ. 2007, 64, 423-432.

13. Meyfroidt, P.; Lambin, E.F. Forest transition in Vietnam and displacement of deforestation abroad. Proc. Natl. Acad. Sci. USA 2009, 106, 16139-16144.

14. Administration, S.F. The Seventh National Survey on Forestry Resources Report (2004-2008). Available online: http://www.forestry.gov.cn/portal/main/s/65/content-326341.html (accessed on 18 September 2014).

15. Lang, G.; Chan, C.H.W. China's impact on forests in Southeast Asia. J. Contemp. Asia 2006, 36, 167-194.

16. Sun, X. Forest Products Trade between China and Africa: an analysis of import and export statistics. Available online: http://www.forest-trends.org/documents/files/doc_4569.pdf (accessed on 22 October 2014).

17. Fearnside, P.M.; Figueiredo, A.M.; Bonjour, S.C. Amazonian forest loss and the long reach of China's influence. Environ. Dev. Sustain. 2013, 15, 325-338.

18. Laurance, W.F. The need to cut China's illegal timber imports. Science 2008, 319, 1184.

19. Wang, G.; Innes, J.L.; Lei, J.; Dai, S.; Wu, S.W. China's Forestry Reforms. Science 2007, 318, 1556-1557.

20. Administration, S.F. Report on National Forestry Economics during the First Half of 2011. Available online: http://www.forestry.gov.cn/portal/main/s/304/content-511728.html (accessed on 18 September 2014).

21. Murray, B.C. Leakage from an Avoided Deforestation Compensation Policy: Concepts, Empirical Evidence, and Corrective Policy Options. In Avoided Deforestation: Prospects for Mitigating Climate; Change Nicholas Institute for Environmental Policy Solutions, Duke University: Durham, NC, USA, 2008; p. 1-32.

22. Hertel, T.W. Global Trade Analysis: Modeling and Applications; Cambridge University Press: Cambridge, UK, 1998.

23. Armington, P.S. A Theory of Demand for Products Distinguished by Place of Production (Une théorie de la demande de produits différenciés d'après leur origine) (Una teoría de la demanda de productos distinguiéndolos según el lugar de producción). Staff Papers Int. Monet. Fund 1969, 16, 159-178.

24. Jiang, H. Roles of CFTR supporting measures in response to Russian rising roundwood export tariffs: Computable general equilibrium analysis using GTAP model. World For. Res. 2012, 25, 63-68. (In Chinese)

25. Schwarze, R.; Niles, J.O.; Olander, J. Understanding and managing leakage in forest-based greenhouse-gas-mitigation projects. Philos. Trans. R. Soc. Lond. Ser. A 2002, 360, 1685-1703. 
26. FAO FAOSTAT. Available online: http://faostat3.fao.org/faostat-gateway/go/to/download/G2/ GF/E (accessed on 18 September 2014).

(C) 2014 by the authors; licensee MDPI, Basel, Switzerland. This article is an open access article distributed under the terms and conditions of the Creative Commons Attribution license (http://creativecommons.org/licenses/by/4.0/). 